\title{
Review
}

\section{Sex Determining Mechanisms in Bivalves}

Sophie Bretona, , Charlotte Capta, Davide Guerra ${ }^{a}$, Donald Stewart ${ }^{\mathrm{b}}$

a Department of Biological Sciences, Université de Montréal, Montréal, QC H3C 3J7 Canada; s.breton@umontreal.ca; charlotte.capt@umontreal.ca; davide.guerra@umontreal.ca

b Department of Biology, Acadia University, Wolfville, NS B4P 2R6 Canada; don.stewart@acadiau.ca

*Corresponding author: Sophie Breton, Department of Biological Sciences, Université de Montréal, CP 6128, Succursale Centre-Ville, Montréal, QC H3C 3J7, Canada, Email: s.breton@umontreal.ca

\begin{abstract}
In this review, we provide an overview of the current knowledge on the different sexual systems and sex determining mechanisms in bivalves, with a focus on the various epigenetic and genetic factors that may be involved. The final section of the review provides recent discoveries on sex-specific mitochondrial genes in bivalves possessing the unconventional system of doubly uniparental inheritance of mitochondria (which is found in several members of the orders Mytiloida, Unionoida, Veneroida and Nuculanoida). The genes involved in this developmental pathway could represent the first sex determination system in animals in which mitochondrially-encoded genes are directly involved.
\end{abstract}

Keywords: sex determination, exual systems, bivalvia, mitochondria

\section{Introduction}

More than 70 years have passed since the pioneering review of W.R. Coe on sexual differentiation in bivalve molluscs (Coe 1943). His review summarized information on the diverse modes of sexual reproduction found in bivalves, ranging from functional (simultaneous) hermaphroditism, alternative sexuality (sequential hermaphroditism), to strict gonochorism or dioecy (i.e., species that exist as separate males and females). Coe concluded that bivalves are predominantly of two sexes and that both genetic and environmental factors are probably responsible for the astonishing variability of sexual conditions observed in the group. Twenty-five years after Coe's review, Purchon (1968) proposed that an ancestral gonochoric condition in bivalves is superimposed on an underlying totipotency of developmental pathways, which facilitated the wide range of sexual forms in a variety of environmental conditions. Haley $(1977,1979)$ was the first to provide evidence that such a system, i.e., the coexistence of multiple possible sexual conditions within one species, is primarily under genetic control in the American oyster, Crassostrea virginica. In many respects, it seems that all these conclusions remain unchanged to this day. That is, the determinants of sex in most bivalves species studied to date appear to be both genetic and environmental, although no systematic overview on this subject has appeared since Coe's seminal work, even if a great deal of new literature has considerably extended our knowledge in this area. For example, Chávez-Villalba et al. 2011 provided an extensive summary in their review of sex determination in the black lip pearl oyster, Pinctada margaritifera.

Such studies are important for several reasons. First, with $\sim 25,000$ living species (14 orders and 105 families [www.bivatol.org]), the class Bivalvia constitutes the second largest class in the Mollusca, which in turn is the second largest animal phylum. Hence, the biology and ecology of bivalves are sufficiently diverse to provide a rich source of material to better understand the evolution of sex and sex determination in general, and to provide unique examples of sex-determining mechanisms, which include the only possible example of mitochondrial genes influencing sex determination pathways in animals (e.g., Breton et al. 2011).

A second reason for studying sex determination in bivalves relates to their intensive use as bioindicators of environmental health (e.g., Campos et al. 2012). If the health status of bivalve populations appears to be 
compromised, with obvious failure or loss of reproductive capacity, information about the factors that affect them can be gained from knowledge of life-history characteristics and population dynamics of the species involved. This implies, to some extent, knowledge of the strategies and mechanisms involved in reproduction and sex determination.

A third and perhaps more immediate practical reason to investigate the mechanisms of sex determination in bivalves relates to their economic and nutritional importance. Millions of people rely on fish and shellfish production as an important source of protein (e.g., Naylor et al. 2000). The bivalve aquaculture industry, i.e., oysters, clams, scallops and mussels, has been steadily increasing over the last 20 years (from $\sim 7$ to 14.5 tons, global production; FAO Global Aquaculture Production Statistical Database), and is projected to increase significantly during the coming decades (Shumway 2011). A better understanding of the reproductive biology of bivalve species is thus of crucial importance for their conservation and for maintaining and restocking populations. As in finfish aquaculture, understanding and controlling bivalve sex and reproductive function can help to reach several important goals, such as producing effectively sterile domesticated shellfish to permit genetic improvement while greatly reducing or eliminating negative interactions with wild stocks (Shumway 2011).

In this chapter, we provide an overview of the current knowledge on the different sexual systems and sex determining mechanisms in bivalves, with a focus on the various epigenetic and genetic factors that may be involved. Epigenetic sex determination (or differentiation) occurs when both sexes can be produced from the same genotype (Beukeboom and Perrin 2014). For our purposes, hermaphroditism will be considered as the product of an epigenetic sexual determination system because within a hermaphroditic individual, genetically identical cell lineages develop into either sperm or eggs. We discuss the different approaches that have been undertaken to elucidate the mode of sex determination in bivalve species including cytogenetic studies, analyses of progeny sex ratios in controlled crosses, experimental manipulation of factors such as ploidy level or environmental rearing conditions, and a variety of more recent 'omics' studies. The final section of this chapter provides an overview of sex-specific mitochondrial genes in bivalves possessing the unconventional system of doubly uniparental inheritance of mitochondria (which is found in several members of the orders Mytiloida, Unionoida, Veneroida and Nuculanoida [Breton et al. 2007; Passamonti et al. 2009; Boyle and Etter 2013; Zouros 2013]). The genes involved in this developmental pathway could represent the first sex determination system in animals in which mitochondrially-encoded genes are directly involved.

\section{Epigenetic determination of sex}

\subsection{Hermaphroditism}

\subsubsection{A multi-faceted minority?}

Hermaphrodite bivalves function both as a female and a male (i.e., egg and sperm producing, respectively) at least once during their life cycle. This two-fold sexual role can be achieved at the same time (simultaneous or functional hermaphroditism) or at different times (sequential hermaphroditism, i.e., sex change, sex reversal, alternating sexuality). The common ground between the two situations is the innate capacity of a single individual, thus a single genotype, to produce both sperm and eggs (see Box 1). This single broad definition of hermaphroditism, however, covers a diverse spectrum of fascinating reproductive strategies and physiological adaptations that are outlined below.

\section{Box 1. Hermaphroditic gonad structure}

The hermaphroditic ability to produce both sperm and eggs is accompanied by specific gonadal organizations that allow for this double capacity. In simultaneous hermaphrodites, the gonad includes the cell precursors of both female and male gametes, and these may be arranged in different ways (Coe 1943, Mackie 1984). In the most common organization, the gonad contains distinct female and male acini in varying proportions, producing eggs and sperm in separate compartments (Sastry 1979): a recent example of such organization was found in hermaphrodite specimens of Anodonta anatina (Unionidae) by Hinzmann et al. (2013). In their work on Atrina seminuda (Pinnidae), Soria et al. (2002) named this gonad organization as "Type 1", and 
also described an additional "Type 2" gonad where acini generate both eggs and sperm, with the first observed at the periphery and the latter at the center of the acinus (a situation also found in the arcid Arca noae by Bello et al. 2013). A more clear-cut possibility is to have two distinct female and male gonads (Coe 1943; Mackie 1984): in some species the color of the two sections can be different, allowing for an easy discrimination of female and male tissues. When discrete female and male gonads or acini are present, gametes can be released through a shared duct or through independent ones (Mackie 1984). Sex changers show only one type of acini during the different sexual phases, and when a transient bisexual condition is present between two single-sex ones, a mixed gonad can be observed, with variable proportions of male and female tissues (Coe 1943). Examples and variations of these basic morphologies enlisted above are described in detail by Mackie (1984).

As mentioned above, the vast majority of bivalve species are reported to be strictly gonochoric with hermaphroditic species thought to be rather uncommon (Coe 1943; Gosling 2015). Coe (1943) suggested that fewer than 400 of the 10,000 described species of bivalves deviated from strict gonochorism and Heller (1993) stated that hermaphroditism is present in only 13 out of 117 bivalve families (taxonomy sensu Vaught 1989). These two reviews, as well as Morton (1991), pointed out that freshwater bivalves are more prone to this reproductive strategy than are marine species. That said, some marine groups, such as oysters, appear to be particularly plastic in their reproductive strategies and show many different variants of hermaphroditism; e.g., at any one time, some oyster populations may be made up of simultaneous hermaphroditic individuals, which also have the potential to change sex between seasons (sequential hermaphroditism) (see Collin 2013). Exceptional hermaphroditic individuals also sometimes appear in otherwise strictly gonochoric species at extremely low frequencies (see Morton 1991 for references) because of what are usually thought to be natural errors during development or the result of chemical pollution that alters the developmental pathway (e.g., Ciocan et al. 2012), neither of which is likely to result in heritable changes in sex determination. However, as we will see, gonochoric populations do sometimes transition to hermaphroditism under certain conditions that, for example, reduce the opportunities for mating, such as low population density or restricted dispersal (e.g., Ghiselin 1969). The true number of species exhibiting a hermaphroditic reproductive strategy (in at least some populations) is inevitably higher than previous estimates. The discovery of new cases of hermaphroditism is hindered by the technical challenges of detecting hermaphrodites within a population. These challenges range from the high degree of invasiveness of sexing techniques on single individuals that is required to determine the type of gonad and gametes produced throughout the life cycle, to the considerable investment required to monitor the sex ratio of a population that is necessary to register gender changes in size- and age-related classes in the case of sequential hermaphrodites.

\subsubsection{How to be hermaphroditic}

Perhaps the simplest situation of hermaphroditism occurs when each individual in a population behaves concurrently as both a functional male and female bearing a combined sperm and ova producing organ, the ovotestis. Such individuals are defined as "simultaneous" or "functional" hermaphrodites. Many species of scallops (family Pectinidae) exhibit this hermaphroditic strategy (Merrill and Burch 1960; Shumway and Parsons 2011). Other examples include giant clams (family Tridacnidae; McKoy 1980) and saltwater clams (order Anomalodesmata; Morton 1981). In these taxa, both types of gametes are produced and discharged simultaneously, but not infrequently a single animal can spawn sperm first and then eggs, a temporal delay that is likely a strategy to avoid self-fertilization (Coe 1943; Gosling 2015). Johnston et al. (1998) demonstrated a fascinating adaptation in the hermaphroditic freshwater mussel Utterbackia imbecillis, namely a negative correlation between rates of selfing and proportion of reproductive tissue devoted to sperm production. This observation is consistent with classic sex allocation theory, which predicts that individuals should reduce proportional male allocation as self-fertilization increases because the pool of eggs available to be fertilized by outcrossed sperm diminishes, and each sperm (or unit of male investment) is competing for fewer available eggs (Charnov 1982).

Another option is what is usually termed sequential hermaphroditism. For example, "sex change" or "consecutive sexuality" refers to a situation where all or some individuals of a species change their functional 
sex once during their life cycle (Coe 1943). The outcome is comparable to gonochorism (i.e., separate sperm and egg producing individuals coexisting within a population at any given point in time), but with the difference that single animals switch from producing one type of gamete to the other at some stage of their life. Protandry, which is the case when an individual is born as or first develops into a male and then becomes female, is more common than protogyny, i.e. when an individual first expresses the female phenotype and then later switches to the male phenotype (Oldfield 1961). The scallop Chlamys varia (Pectinidae) is a classic example of a protandric species (Lubet 1959, Lucas 1965). Burnell (1995) studied two geographically separate populations of C. varia on the west coast of Ireland that exhibited different growth rates, and found that male-to-female sex change was correlated with age and not size (i.e., height): indeed, cohorts of the same age had different sizes in the two localities, but the sex ratio was comparable, with younger individuals being mostly males. He suggested that the sex change occurs during the resting stage in the second growing season, possibly triggered by the accumulation of some energetic storage products during winter.

Protandric sex change can also be related to the size of an individual and to the resources it can allocate to produce gametes, rather than to its age (see Figure 1). Below a certain size, being female can result in a lower reproductive success compared to being a male, in that a small individual can allocate limited reserves into gamete production that can be better used in generating sperm, which require less energy-demanding resources than eggs. Above a certain size, the reproductive success for being a female becomes higher (larger females have

A

RS

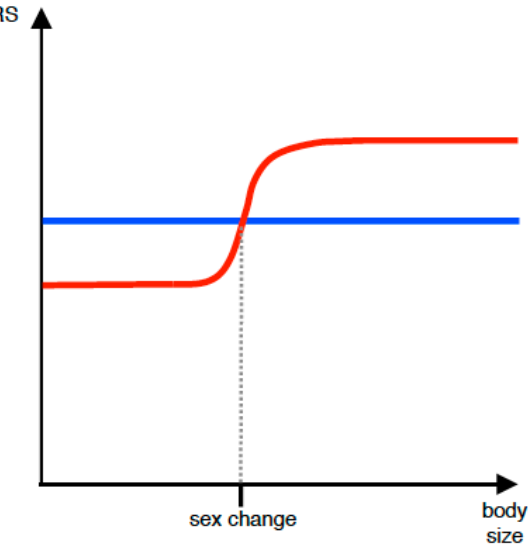

B

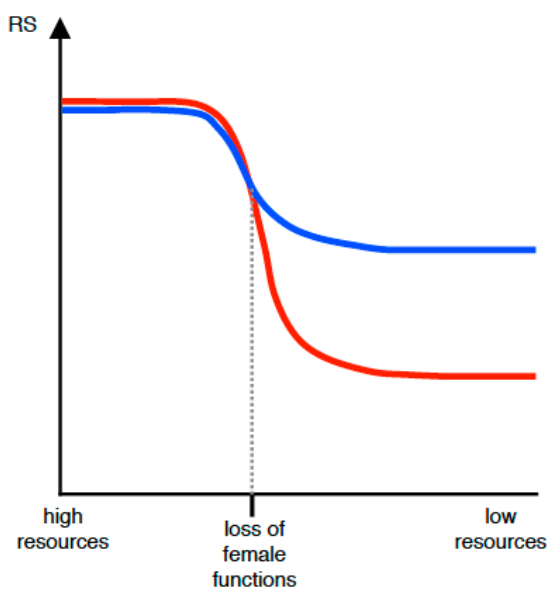

Figure 1. Two models for sex change in bivalves. RS, reproductive success; red line, female RS; blue line, male RS. The trends of RS in both panels are not based on actual experimental data and are solely an interpretation made by the authors meant to give a visual idea of the models. (A) Size advantage model as described by Policansky (1982). Male RS is independent of body size, while female RS is proportional to dimension. Small males have a higher RS compared to females of the same size, since the cost of producing sperm is lower than that of eggs, but after a certain threshold size females have higher RS than males, since they can produce eggs more efficiently than the smaller ones. In protandric sex changing bivalves, an individual born as a male can thus switch its sex to female when it reaches the threshold size to increase its own RS. It is not specified however if the RS of smaller females after the sex change is lower than that of bigger ones, or if also male RS increases with size, so we depicted the first reaching a plateau value after the sex change and the second being constant to focus on the differences in RS around the sex change size. (B) Resource availability model inferred from the results of works cited in paragraph 2.2.3. RS of females and males is proportional to the available resources (food, body nutrients) or to the capacity to accumulate them (e.g., fully functioning feeding ability). When resource availability decreases, RS also decreases for both sexes, but the female falls faster than the male one since eggs require more resources per unit to be produced compared to spermatozoa. Beyond a threshold value of resource accessibility, females have lower RS than males: under these conditions, a female can switch sex and become male to maintain a better RS. In simultaneous 
hermaphrodites, female functions can be stopped in favor of only the male ones when resources are lacking.

a higher capacity for egg production), and a male can then change sex (Ghiselin 1969; Charnov 1982; Policansky 1982). In this scenario, the overall sex ratio of a population can be $\sim 1: 1$, but that of single cohorts can be skewed toward one sex or the other (i.e., initially more males in smaller, younger individuals and subsequently more females in larger, older individuals). Finally, intermediate phases of simultaneous hermaphroditism can occur during the protandric sex change, as observed in the Noah's ark shell Arca noae (family Arcidae) (Bello et al. 2013).

As noted above, the phenomenon of protogyny is rare, but it is the rule in a few species such as the galeommatoids Kellia suborbicularis (Laseidae) and Montacuta substriata (Montacutidae) (Oldfield 1961). Exceptional cases of protogyny have also been reported in scallops, specifically within the genus Pecten (Pectinidae) (Coe 1943). Female-to-male sex change may be driven by low available resources intake (Figure 1 and below for more details). Hermaphroditic species of freshwater Corbicula clams (Corbiculidae) are also protogynous, with eggs present year-round and sperm produced in response to seasonal changes in temperature (Pigneur et al. 2012). Corbicula clams, together with the little fire ant, Wasmannia auropunctata, only two cases of obligate androgenesis in animals, and the only one for which the cytological mechanisms of androgenetic reproduction have been well described (see Pigneur et al. 2012 for a review). In this atypical mode of asexual reproduction, the maternal nuclear genome fails to participate in zygote development and offspring are paternal nuclear clones. Cytological studies show that in androgenetic Corbicula, a diploid spermatozoon fertilizes the oocyte, the maternal nuclear contribution is extruded as two polar bodies, and the maternal organelles are retained (Pigneur et al. 2012). Although the mechanism that causes unreduced sperm still remains unknown, the authors suggest that androgenetic reproduction might have been partly responsible for the invasive success of freshwater Corbicula clams (Pigneur et al. 2011, 2012). Because androgenetic Corbicula are hermaphroditic and capable of self-fertilization, a single individual can establish a new population in any new suitable niche, and each individual can have up to 90000 offspring per reproductive season (McMahon, 1999). With sufficient clonal diversity due to new mutations or to colonization by different genotypes, a successful clone associated with high levels of plasticity and broad environmental tolerance could be selected for, and in the long term, a "generalpurpose" genotype could evolve (Van Doninck et al. 2002; Pigneur et al. 2012).

Protogynic sex change is also an integral element of two other categories of sequential hermaphroditism. The oyster Ostrea edulis is an example of what Coe (1943) defines "rhythmical consecutive sexuality". Individuals in this species usually complete a male and a female phase, i.e., they release sperm and eggs at different times, each reproductive season. After sperm release has been completed, egg production is started but, depending on the time of the year, their release can follow immediately or be delayed until the next reproductive season. This means that the sexual phases are not perfectly synchronized in all individuals, which results in a mixed sex population throughout the breeding season. Again, as seen for other strategies above, the first functional phase is male, although some exceptions have been observed (Coe 1943). Oviparous oysters such as Crassostrea virginica, on the contrary, act only as one sex during a single reproductive season, and in the following year the functional sex can change or remain the same, a strategy called "alternative sexuality" by Coe (1943).

The effects of the environment on gender determination have mostly been studied in hermaphroditic species. Indeed, because sacrificing the animal is often required to determine its sex and because sexual maturation, which varies among species, can take several months or years (Gosling 2015), most studies have investigated the environmental effects on sex differentiation in adults in sequential hermaphroditic species, principally because they can undergo sexual reversion. Therefore, the possible influence of the environment on determining sex before first gonadic differentiation is still poorly known and the underlying mechanisms remain virtually unstudied. The following sections present an overview of recent information that relates the effects of the environment on sex determination before and after first gonadic differentiation in bivalves.

\subsection{Environmental effects on sex determination}


Several bivalve species have been investigated through sex ratio studies in which the stability of sex determination or differentiation was tested using a variety of abiotic and biotic factors known to affect the process of sex determination in other mollusc or invertebrate species (e.g., Heller 1993; Chávez-Villalba et al. 2011; Collin 2013). For example, exogenous steroids, temperature, food availability and pollutants have all been tested and been shown to affect sex ratios in bivalves (a summary of which is presented in Table 1). 
Table 1. Environmental effects on sex ratios

\begin{tabular}{|c|c|c|}
\hline Factor/Species & Treatment and/or main results & References \\
\hline $\begin{array}{l}\text { Exogenous steroids } \\
\text { Crassostrea gigas } \\
\text { Mulinia lateralis } \\
\text { Placopecten } \\
\text { magellanicus }\end{array}$ & $\begin{array}{l}17 \beta \text {-estradiol: feminizing effect (with observed sex } \\
\text { reversals) } \\
\text { methyltestosterone: masculinizing effect } \\
17 \beta \text {-estradiol, testosterone, progesterone, } \\
\text { dehydroepiandrosterone } \\
\text { (DHEA): masculinizing effect (with observed sex } \\
\text { reversals) }\end{array}$ & $\begin{array}{l}\text { Mori et al. } 1969 \\
\text { Moss } 1989 \\
\text { Wang and Croll } 2004\end{array}$ \\
\hline $\begin{array}{l}\text { Temperature } \\
\text { Crassostrea corteziensis } \\
\text { Crassostrea gigas }\end{array}$ & $\begin{array}{l}\text { males at } 18^{\circ} \mathrm{C} ; \quad \text { females at } 9^{\circ} \mathrm{C} \\
\text { females at higher temperatures; males at lower } \\
\text { temperatures }\left(8^{\circ} \mathrm{C}\right) \\
\text { females at higher temperatures } \\
\text { males at higher temperatures } 28^{\circ} \mathrm{C} \text { (combined with low } \\
\text { food availability) }\end{array}$ & $\begin{array}{l}\text { Chávez-Villalba et al. } \\
\text { 2008; } \\
\text { Rodriguez-Jaramillo et al. } \\
2008 \\
\text { Fabioux et al. 2005; } \\
\text { Lango-Reynoso et al. } \\
\text { 2006; } \\
\text { Santerre et al. } 2013 \\
\text { Coe } 1936 \\
\text { Teaniniuraitemoana et al. } \\
2016\end{array}$ \\
\hline $\begin{array}{l}\text { Food availability } \\
\text { Argopecten irradians } \\
\text { Crassostrea gigas } \\
\text { Mytella charuana } \\
\text { Pinctada margaritifera }\end{array}$ & $\begin{array}{l}\text { males with low food availability (combined with low } \\
\text { temperatures) } \\
\text { males with low food availability } \\
\text { males with low food availability } \\
\text { males with low food availability (combined with high } \\
\text { temperatures) }\end{array}$ & $\begin{array}{l}\text { Sastry } 1968 \\
\text { Lango-Reynoso } 1999 \\
\text { Stenyakina et al. } 2010 \\
\text { Teaniniuraitemoana et al. } \\
\text { 2016; Chávez-Villalba et } \\
\text { al. } 2011\end{array}$ \\
\hline $\begin{array}{l}\text { Pollution } \\
\text { Gomphina veneriformis } \\
\text { Mya arenaria }\end{array}$ & $\begin{array}{l}\text { males with tributyltin } \\
\text { males with tributyltin }\end{array}$ & $\begin{array}{l}\text { Park et al. } 2015 \\
\text { Gagné et al. } 2003\end{array}$ \\
\hline
\end{tabular}

\subsubsection{Exogenous steroids}

Following the discovery of a role of sex hormones in the hormonal regulation of bivalve reproduction (Mackie 1984; Chávez-Villalba et al. 2011; Teaniniuraitemoana et al. 2016), a role that was suggested to be similar to that in vertebrate endocrine systems, several studies have attempted to control the reproductive state of cultured bivalves using exogenous steroids (see Croll and Wang 2007 for a review). However, only a small number of these studies demonstrated that the sex of bivalves can be affected by steroid hormones (i.e., by the demonstration of sex reversal of adult individuals) and none of them explored the underlying mechanisms (Table 1). To our knowledge, only one study by Wang and Croll (2004) investigated the possible effects of steroid hormones on sex determination at the juvenile stage before first gonadic differentiation. These authors injected adductor muscles of juvenile sea scallops Placopecten magellanicus with 17 $\beta$-estradiol, testosterone, 
progesterone or dehydroepiandrosterone (DHEA), and showed that these treatments accelerated gonadal differentiation, and in some cases shifted observed sex ratios toward males. These results were interpreted as evidence that sex steroids may be involved in sex determination in bivalves as they are in vertebrates (Wang and Croll 2004; Croll and Wang 2007); however, more research is obviously needed to better understand the precise mechanisms underlying these developmental pathways.

\subsubsection{Temperature}

An effect of temperature on sex determination has been observed in multiple animal species including vertebrates (e.g., reptiles, amphibians and fishes) and invertebrates (e.g., rotifers, nematodes, insects, crustaceans and molluscs; Korpelainen 1990). Temperatures above or below a threshold value appears to affect gender determination during a critical time window called the "thermo-sensitive period" (TSP), and thus progeny developing within a particular temperature regime during this TSP consists solely of males or females (Manolakou et al. 2006). The TSP occurs once during the period of sexual maturation in gonochoric species and during each sex reversion period in hermaphroditic taxa. In bivalves, a temperature effect on sex has only been studied in sequential hermaphroditic oysters, in both adults (in natural populations and under controlled conditions) and spat (i.e., before sexual maturation; under controlled conditions) (Table 1). For example, Coe (1936) observed a female-biased sex ratio at high temperature in natural populations of the Eastern Oyster, Crassostrea virginica. Similarly, Lango-Reynoso et al. (2006) reported that the sex ratio in wild populations of $C$. gigas changed from heavily female-biased during the summer to male-biased in winter, although the proportion of undifferentiated individuals significantly increased over the fall and winter months. In this species, a oneyear conditioning at low temperatures $\left(8^{\circ} \mathrm{C}\right)$ led to a male-biased sex ratio (Fabioux et al. 2005), consistent with the field data of Lango-Reynero et al. (2006). Finally, a different pattern of sex ratio effects related to temperature was reported for the tropical Cortez oyster Crassostrea corteziensis in which higher proportions of males were observed at or above $\sim 18^{\circ} \mathrm{C}$ (Chávez-Villalba et al. 2008) whereas more females were observed below $\sim 9^{\circ} \mathrm{C}$ (Rodriguez-Jaramillo et al. 2008).

Again to our knowledge, just as only a single study has been conducted on the effects of sex hormones on immature bivalves, only one study has investigated the effects of temperature on sex determination on juveniles before the first signs of gonadic differentiation. Specifically, Santerre et al. (2014) investigated the effect of four different temperature regimes $\left(18,22,25\right.$ and $28^{\circ} \mathrm{C}$, respectively) on sex determination in Pacific oyster C. gigas spat, and observed a significant increase in the frequency of males at $25^{\circ} \mathrm{C}$. Interestingly, the authors assessed in parallel mRNA expressions of five putative actors of the molecular cascade of sex determination/gonadic differentiation pathway previously characterized in this species (i.e., the genes $\mathrm{Cg}$-Foxl2, Cg-Foxl2os, Cg-DMl, $\mathrm{Cg}$ SoxE and Cg- $\beta$-catenin; Naimi et al. 2009a,b; Santerre et al. 2012), and showed that this increase in males was associated with a change in the balance of expression of male and female genes, in favor of male orthologs such as $C g$-DMl and $C g$-SoxE (Santerre et al. 2014). These mRNA expression profiles also suggested a time window of sex determination in spat at around $40-44$ days post fertilization (dpf) at $18^{\circ} \mathrm{C}$, in agreement with previous studies which suggested that sex determination may occur at around 45-60 dpf (Naimi et al. 2009b; Santerre et al. 2014). Such effects, i.e., an influence of temperature on the mRNA expression profiles of sex-determining genes, had already been demonstrated in species with temperature-dependent sex determination (TSD), such as in reptiles and fishes (e.g., Rhen et al. 2007; Yamaguchi et al. 2007; Shoemaker-Daly et al. 2010). However, the case of $C$. gigas spat differs slightly because the influence of temperature on the oyster sex determination is apparently responding directly to genetic control (see below), suggesting a mixed sex determination system (Genetic sex determination [GSD] + TSD; Santerre et al. 2013). Additional 'omics' studies of this kind will help to further decipher the system of sex determination in oysters (and other bivalve species), and enrich the current information available on the mechanisms involved in temperature-dependent determination in invertebrate species.

\subsubsection{Food availability}

Recently, Teaniniuraitemoana et al. (2016) examined the effect of environmental combinations of 
temperature $\left(24\right.$ and $28^{\circ} \mathrm{C}$ ) and food availability (trophic level; 10,000 and 40,000 microalgae cells $\mathrm{mL}^{-1}$ ) on gender determination in adult black lip pearl oysters, Pinctada margaritifera. Their results showed a significant effect on sex ratio for oysters conditioned at high temperature and low food concentration with a significant proportion of females $(50 \%)$ changing to males under those conditions (Teaniniuraitemoana et al. 2016). The authors invoked an energetic deficit as the potential cause of the female-to-male sex change; they specifically argued that the increase in oxygen consumption and metabolic rate at high temperature depleted the energetic reserves required for the production of female gametes, which is hypothesized to be more energetically costly than the production of male gametes in mollusc species (Russell-Hunter 1979). The ability to switch to being male in poorly fed female oysters is presumably an adaptive response. This was the conclusion of a previous study by Stenyakina et al. (2010) that demonstrated changes in sex from female to male in adult marine Charru mussels, Mytella charruana. These authors showed that mussels collected from different natural populations and maintained in the laboratory with or without food exhibited a male-biased shift in sex ratio under starvation conditions within a month (Stenyakina et al. 2010). This is also in agreement with previous observations in natural populations of hermaphroditic scallops (Sastry 1968) that showed a correlation between a higher proportion of males and a combination of low food supply and cooler temperatures. Similar patterns have also been demonstrated in laboratory reared and natural populations of Pacific oysters (Lango-Reynoso 1999; Chávez-Villalba et al. 2011); i.e., a sex ratio in favor of females was noted when food availability conditions were favorable. Apparently, any situation that lowers body nutrient reserves and/or food intake (e.g., removal of gills, starvation, parasitic infections), always leads to a rise in the percentage of males in populations of bivalves capable of changing sex (Amemiya 1935; Egami 1953; Bahr and Hillman 1967; Davis and Hillman 1971; Cox and Mann 1992).

As part of their study on the effects of temperature and food availability, Teaniniuraitemoana et al. (2016) also investigated patterns of mRNA expressions for nine marker genes of the sexual pathway (pmargfoxl2, pmargc43476, pmarg-c45042, pmarg-c19309, pmarg-c54338, pmarg-vit6, pmarg-zglp1, pmarg-dmrt, and pmarg-fem1-like). According to their results, only pmarg-foxl2 and pmarg-fem1-like were significantly differentially expressed between male and female P. margaritifera, suggesting that these two genes are involved at the top of the molecular cascades of sex determination in black lip pearl oysters (Teaniniuraitemoana et al. 2016). As was proposed for C. gigas by Santerre et al. (2014), Teaniniuraitemoana et al. (2016) also suggested that there is a mixed sex determination system in $P$. margaritifera that involves both genetic and environmental factors. However, because the latter work focused on sex change in adults, additional studies will need to be conducted on juvenile spat before expression of first signs of gonadic differentiation. The genes pmarg-foxl2 and pmarg-fem1like are likely the best candidate genes to be first explored in further genomic studies of the mechanisms of sex determination in pearl oysters.

\subsubsection{Pollution}

Relatively little information exists in the literature on the effects of environmental pollutants on bivalve sex determination and differentiation, or reproductive patterns generally (e.g., Gauthier-Clerc et al. 2002; Gagné et al. 2003; Park et al. 2015). However, the complexity of cellular processes involved in sex change and/or gonad differentiation and maturation, certainly provide an opportunity for chemical interference in the pathways leading to the development of females or males. Indeed, several pollutants, such as heavy metals, organophosphates and organochlorines, are known to interfere with the natural role of hormones and consequently affect sex determination, gonad morphology, gametogenesis, and reproduction in molluscs (Park et al. 2015). One infamous example is tributyltin (TBT), an organotin compound that has been largely used as a biocide in antifouling agents for boats, and which is now well-established as a xenoandrogen that skews sex ratios toward males in both wild and reared populations of several mollusc species, including bivalves (Table 1). These observations suggest that pollutants currently found in aquatic habitats are able to affect sex determination and differentiation pathways in bivalves. As with the case for the effects of food availability, additional studies are needed to identify the precise biochemical mechanisms and genes involved, and also to identify other chemicals that might be involved in the process of endocrine disruption by environmental 
pollutants in bivalves.

\subsubsection{Influence of other abiotic or biotic factors}

Other examples of abiotic or biotic effects on sex ratios in bivalves have been noted. For example, some studies of oysters have reported an influence on sex by social factors, i.e., by other individuals living in close proximity probably through secretion of pheromone-like compounds (e.g., Kennedy 1983). Some other studies have reported pronounced phenotypic plasticity of sexual systems in bivalves in response to environmental conditions (Collin 2013). Bivalves are generally sessile animals. Many species do not move after settlement, and they simply reproduce by releasing gametes into the water column (Gosling 2015). This is the rule at least for sperm but not necessarily eggs, because females of some species retain them in dedicated body parts and fertilize them with sperm extracted from the water column (or from their own body in the case of self-fertilizing hermaphrodites) (Gosling 2015). In broadcast spawning species, spermatozoa actively swim (guided by chemical signals; e.g., Evans and Sherman 2013) until they encounter an egg in the open water (external fertilization, as in the majority of marine species), or until they are taken in passively through the inhalant opening by a female (internal fertilization, as in freshwater mussels of the order Unionoida) (Gosling 2015). There may be situations in which the probability that eggs and sperm can meet will be low: for instance, at low population densities the physical distance among individuals may be relatively large (Ghiselin 1969; Charnov et al. 1976). Environmental variables, such as extremely weak or extremely strong water currents, etc., may also limit fertilization success regardless of population density. In these instances, natural selection may favor hermaphrodites, as their mating chances are improved compared to single-sex individuals (Downing et al. 1989), as will be discussed in the next few case-studies.

The numerical decline of some Mexican populations of the gonochoric chocolate clam, Megapitaria squalida (Veneridae), might have triggered a rise in the incidence of hermaphroditism. Romo Pinera et al. (2009) investigated sex ratio and occurrence of hermaphroditism in two populations of this commercially exploited species, which has been subjected to an approximately 30 times increase in fishing activity in recent years. An unusually large proportion of hermaphrodites was found (21.8\% and $23.5 \%)$, much higher compared to earlier reports from different localities $(0 \%, 0.25 \%$, and $2.6 \%$; see references in Romo Piñera et al. 2009) and to classical estimates $(0.1-7 \%)$ of incidental hermaphroditism in other gonochoric species by Morton (1991). Also, a sex ratio skewed toward females was observed for the first time in this species. The reduction in population density might have given an advantage to hermaphrodites, according to Ghiselin (1969) and Charnov et al. (1976), and a female-biased sex ratio may be an additional strategy adopted to maximize population reproductive success (Avise 2011).

Hinzmann et al. (2013), on the other hand, provided instead a putative example of environment-driven increased hermaphroditism in the gonochoric freshwater mussel Anodonta anatina (Unionidae). Iberian populations from standing waters showed a higher incidence of hermaphrodites than those of river environments (an observation comparable to one made on Ukrainian populations of the same species; Yanovych et al. 2010). This may be caused by differences in gamete dispersal (freshwater mussels do not release eggs) between the two environments, with stronger currents in rivers diffusing sperm more efficiently than is possible in lagoons. In other words, being a hermaphrodite may be a better reproductive strategy for A. anatina in standing waters where sperm dispersal can be limited. The cause-effect link among decreasing populations, changing/different environmental conditions, and hermaphrodite percentage in freshwater mussel populations may be difficult to disentangle. Galbraith and Vaughn (2011) studied the negative effects of human-adulterated regimes of water currents and temperature in dam reservoirs on the reproduction and population dynamics in three Quadrula species (Unionidae). The most altered environment showed the most sparse populations and the highest proportions of hermaphrodites: these effects were mainly linked to the different temperatures (i.e., colder temperatures than usual), which could have affected sperm motility, leading to a decrease in population density, and the "normal" gonochoric sex determination pattern. However, a density-dependent response to a changed environment similar to that suggested by Hinzmann et al. (2013) for the increase in the incidence of hermaphroditism should also be taken in account. 
From these examples it appears that bivalves are able to respond to a changing environment by adapting their sexuality on a microgeographic scale, suggesting a highly plastic reproductive capacity even at population and individual levels. At the macroevolutionary level, natural selection might have molded this reproductive capacity of bivalves in an environment-specific way: gonochorism is almost the rule, but hermaphroditism has evolved several times resulting in a number of different simultaneous and sequential variants. Morton (1991) proposed a model linking reproductive strategy of bivalves and environment after having found a general pattern by comparing incidence of hermaphroditism and sex ratio variations in whole populations and cohorts of diverse ages in several bivalve species from various habitats in Hong Kong. In small river habitats, species showed a tendency towards simultaneous hermaphroditism and brooding, whereas other freshwater environments such as lakes and large rivers were home to gonochoric species with populations biased towards females. Sequential hermaphroditic species that showed juvenile male-to-female sex change were present in estuarine environments, with varying overall sex bias, and intertidal marine habitats hosted mostly gonochoric species without evidence of simultaneous or sequential hermaphroditism. All these strategies are adopted to maximize reproductive success of individuals within a population to their own particular environment. Obviously, a 'wrong' strategy in the 'wrong' habitat could lead to local extirpation, or even species-level extinction, and would not persist. The tendency of diverse bivalve species to use comparable strategies in similar environments might be an indication of the highly responsive capacity of these animals to changing habitats, a quality that might have played a crucial role in their evolutionary success. The "Hong Kong model" by Morton (1991) surely deserves more consideration if we want to understand the basis of bivalve reproductive biology.

\section{Genetic determination of sex}

The genetic mechanisms of sex determination in bivalves have been better clarified by several types of experiments, such as cytogenetic and sex ratio studies, identification/isolation of sex-specific DNA markers using differential expression analyses, and surveys and comparisons of genomes and/or transcriptomes. Several of these putative mechanisms are discussed below.

\subsection{Cytogenetic or molecular evidence for sex chromosomes in bivalves}

The quickest approach to elucidate the genetic determinants of sex in a species is to examine the karyotype of male and female individuals in an attempt to identify sex chromosomes. To date, more than 150 species of bivalves have been cytogenetically characterized (Menzel 1968; Ahmed 1973; Wada 1978; Cornet and Soulard 1989, 1990; Thiriot-Quiévreux and Insua 1992; Thiriot-Quiévreux 2002; Leitão and Chavez 2008; Jenkinson 2014), and none has been found to possess heteromorphic sex chromosomes. Had such chromosome been found, their mode of sex determination could have been undeniably defined as genetic. One bivalve species, though, has been suggested by Guo and Allen (1994) to have an XX-female, XY-male sex determination with Y-domination, namely the dwarf surfclam, Mulinia lateralis. The authors came to this conclusion after having induced diploid gynogenetic as well as triploid M. lateralis and observed that all gynogenetic diploids were female, and that there was no significant difference in sex ratio between 'regular' diploids and triploids. Similarly, Allen et al. (1986) produced triploid soft-shell clams Mya arenaria but based on the observed sex ratio (triploids were $77 \%$ females), concluded that sex determination in this species best fits the model of an X:autosome balance mechanism as found in insects. Overall, the absence of heteromorphic sex chromosomes in bivalves, together with the environmental factors discussed above and known to contribute to sex determination, illustrate the underlying complexity and lability of the process in this group, and point to a polygenic architecture of sex determination, which is discussed below.

\section{2 (Poly)genic sex determination in bivalves}

The genetic determinants of sex in bivalves have also been investigated through analysis of family sex ratios, leading to the development of genetic models without knowledge of molecular mechanisms of sex determination (e.g., Haley 1977, 1979; Guo et al. 1998; Hedrick and Hedgecock 2010). For example, based on observations of sex ratio variation among five families of the Eastern oyster Crassostrea virginica, Haley (1977, 
1979) proposed a three-loci model for sex determination, with two additive alleles at each locus, one for maleness (m) and one for femaleness (f), and the m:f ratio determining sex. Guo et al. (1998) analyzed sex ratios in 86 pair-mated families of the Pacific oyster $C$. gigas and provided evidence for a single-locus model of primary sex determination with a dominant male allele $(\mathrm{M})$ and a protandric female allele $(\mathrm{F})$, so that $\mathrm{FM}$ oysters are true males and FF are protandric females that are capable of sex change. The authors also suggested that the rate of sex change of FF individuals could be influenced by secondary genes and/or environmental factors (Guo et al. 1998). However, because this 2-genotype model could not explain observed heterogeneity of sex ratios in halfsib families with a single male parent and different female parents, Hedrick and Hedgecock (2010) proposed an alternative 3-genotype model with two kinds of females, fixed FF and protandric FM; the model involves an " $\mathrm{f}$ " parameter, which is the probability that FM individuals mature as females, explaining heterogeneity in sex ratios.

Owing to their importance in aquaculture and fisheries, the interest in bivalve genomics and transcriptomics to identify the genes involved in reproduction, sex differentiation and sex determination processes has significantly increased in recent years (e.g., Dheilly et al. 2012; Ghiselli et al. 2012; Zhang and Guo 2014; Shi et al. 2015; Tong et al. 2015; Teaniniuraitemoana et al. 2014, 2016). However, because this is beyond the scope and goals of the present review, studies relating genes involved in reproduction or in later steps during sexual differentiation are not discussed. Here we provide an overview of recent information on genes known to act in sex determination in other animal species (invertebrates and vertebrates) and/or during early gonadal differentiation, and thus potentially might play a role in sex determination in bivalves (because no genes are currently known with certainty to be involved in the initial sex-determination process in this group).

Ghiselli et al. (2012) published the first whole transcriptome analysis by RNA-Seq performed to identify genes involved in bivalve sex determination. By comparing transcriptomes of males and females in the Manila clam Ruditapes philippinarum, they identified 1,575 genes with strong sex-specific expression including the malebiased gene Sry (sex determining region-y)-box 30 (Sox30), a transcription factor involved in the differentiation of developing male germ cells in mammals (Wallis et al. 2008; Ghiselli et al. 2012). Because Sox30 was not only highly expressed in testis but also in females producing male-biased progenies, the authors suggested that this gene was expressed in eggs of male-biased mothers to induce the development of future embryos towards maleness (Ghiselli et al. 2012).

Genes homologous to sex determining pathway genes in model species have also been identified in several other bivalve species. In scallops for example, a homolog of Dmrt1 (doublesex and mab-3 related transcription factor 1), which is well known for its conserved role in male sex determination and differentiation in a large panel of animal taxa including fruit flies, C. elegans and vertebrates (Kopp 2012), has been identified in the hermaphroditic scallop species Nodipecten subnodosus (Llera-Herrera et al. 2013). Jiao et al. (2014) reported in the hermaphrodite scallop, Chlamys farreri, the existence of Znfx1 (Nfx1-type zinc finger-containing 1), a gene tightly linked with Amhr2 (anti-Mullerian hormone receptor type II), which is involved in early steps of male sex determination in mammals and in sex determination in the tiger pufferfish Takifugu rubripes (Kamiya et al. 2012).

In freshwater mussels, an in-depth study of sex-specific genes has recently been conducted on sperm and ovary tissues of the gonochoric species Hyriopsis schlegelii (Shi et al. 2015). A total of 45,422 unigenes were found to be differentially expressed between the ovary and sperm and among them, key genes reported to govern sexdetermination pathways in mammals were identified, including Sry, Dmrt1, Dmrt2, Sox9, GATA4 and WT1, which were upregulated in males, and Wnt4, Rspo1, Foxl2, and $\beta$-catenin, which were upregulated in females (Shi et al. 2015). These results suggest that $H$. schlegelii and mammals use similar gene regulatory mechanisms to control sex determination (Shi et al. 2015). Broadly, male sex determination in mammals is initiated by the expression of Sry (Sex-determining region on Y), which suppresses ovarian promoting genes and activates Sox 9 (Sry-box 9), a key element of the testis-determining cascade leading to the activation of Dmrt1 and differentiation of Sertoli cells, whereas female sex determination is initiated by the forkhead box transcription factor Fox $22, \beta-$ catenin and Wnt4, which promotes and maintains ovarian development while suppressing Sox9 (Veitia 2010). Because hermaphroditism has already been noted in H. schlegelii, Shi et al. (2015) also focused their efforts on searching for key genes known to regulate sex determination in other hermaphroditic model species, such as Caenorhabditis elegans. Interestingly, genes associated with hermaphrodite phenotypes in the roundworm $C$. 
elegans, i.e., Tra-1, Tra-2 $\alpha$, Tra-2 $\beta$, Fem1A, Fem1B, and Fem1C (reviewed in Gamble and Zarkower 2012), and genes associated with dosage compensation mechanisms in the fruit fly Drosophila, such as Msl1, Msl2, and Msl3 (Legube et al. 2006), were also identified in H. schlegelii, suggesting that diverse regulatory mechanisms regulate sexual polymorphism in this species (Shi et al. 2015).

The genetic mechanisms of sex determination have been studied more in detail in oysters than in any other group of bivalves. Among the genes that are known to act in sex determination in other animal species and/or during early gonadal differentiation, and thus potentially in sex determination in oysters, there are: Oyvlg (Crassostrea gigas; Fabioux et al. 2004, 2009), a homologue of vasa, which is a gene involved in primordial germ cell development and early sex differentiation in eukaryotes; Cg-DMI (C. gigas Dmrt-like; Naimi et al. 2009), a homologue of Dmrt1 (other homologues of Dmrt1 have also been reported in the oysters Pinctada martensii and P. margaritifera; Yu et al. 2011; Teaniniuraitemoana et al. 2014); Cg-SoxE, a homologue of Sox9, and $\beta$-catenin, which are respectively expressed when sex is still not distinguishable, or in mature females and vitellogenic oocytes in C. gigas (Santerre et al. 2014); and CgFoxL2, CgSoxH (or Sry-like) and CgDsx (C. gigas; Zhang et al. 2014), the two latter genes being linked to the triggering of male development. Vasa, FoxL2 and $\beta$-catenin have also been reported in the species Crassostrea hongkongensis (Tsuda et al. 2003; Tong et al. 2015). In addition, FoxL2 has been reported in Pinctada margaritifera (Teaniniuraitemoana et al. 2015), and vasa in Pinctada fucata, together with other sex-specific genes acting on early steps of the sex determination process, including nanos, doublesexand mab-3-related transcription factor (Matsumoto et al. 2013). All the above genes are thought to be involved in sex determination and early oyster gonadic differentiation. Their conservation among vertebrates and molluscs suggests a deeply evolutionary conserved role in the sex determination process.

Zhang et al. (2014) proposed a working model for sex determination in the Pacific oyster Crassostrea gigas (Figure 2). This species is characterized by protandry, sex change, and rare but consistent hermaphroditism, and the initiation of sex determination is thought to involve both genetic and environmental factors (Zhang et al. 2014). Based on sequence homology and functions inferred from transcriptome data, Zhang et al. (2014) speculated that $\mathrm{CgSoxH}$, a Sry-like gene that is strictly expressed in testis, may play a leading role in the sexdetermining pathway of $C$. gigas. $C g S o x H$ would directly or indirectly activate $C g D s x$, a DM domain gene like those (e.g., Dmrt1) that have been identified as master switches for testis development in all metazoans studied so far. Both CgSoxH and CgDsx would interact with, or inhibit, CgFoxL2, which is usually specifically expressed in ovaries. The possible interaction among these male- and female-promoting genes is consistent with the reported interaction among Sry, Sox9, Dmrt1, and FoxL2 in mammals (Veitia 2010, Zhang et al. 2014) (Figure 2). This working model provided by Zhang et al. (2014) will certainly stimulate further investigation on sexdetermining pathways in molluscs and other invertebrates. 


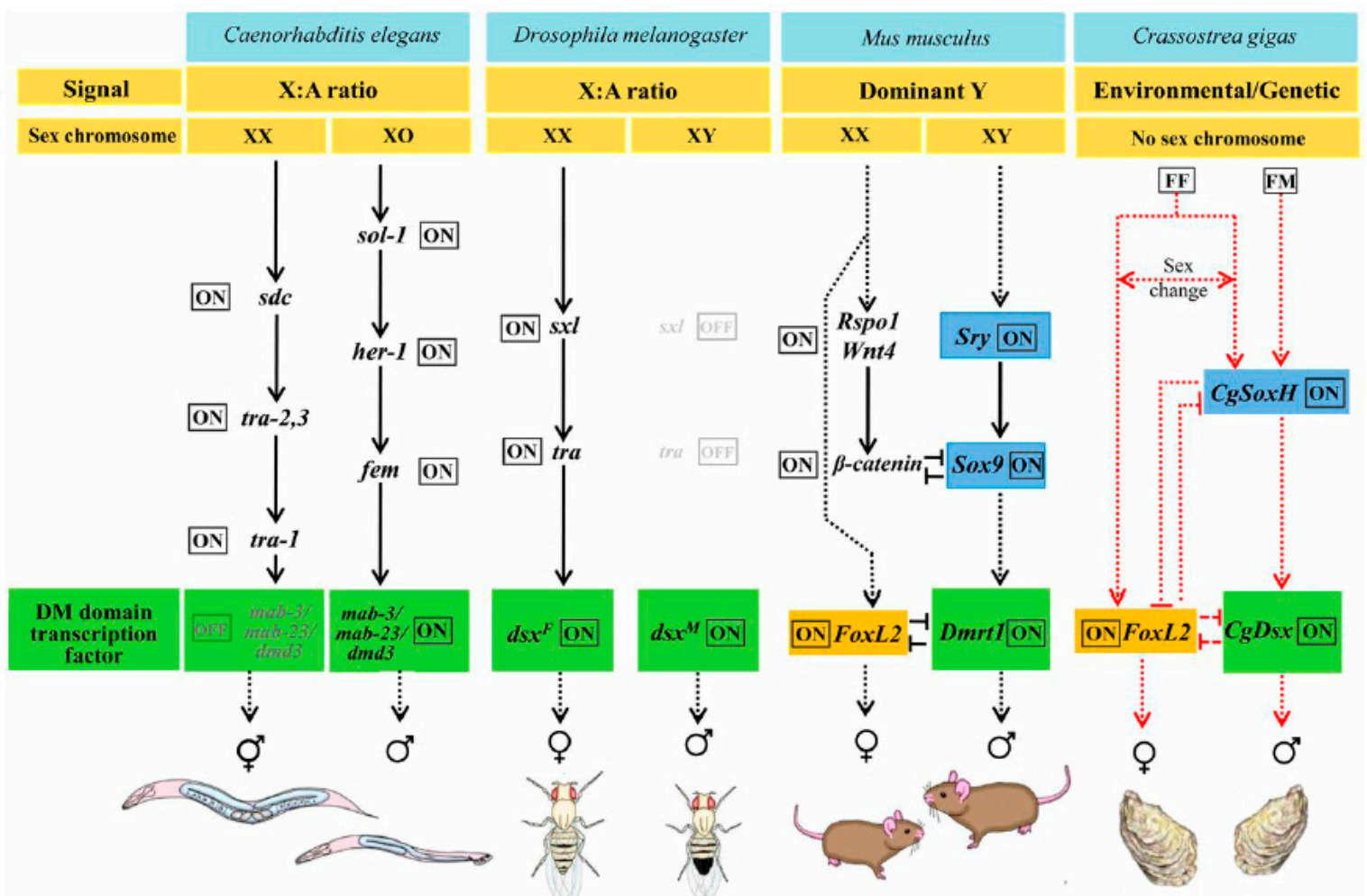

Figure 2. Working model for sex determination in the Pacific oyster Crassostrea gigas. Sex-determining pathway in C. gigas is compared with that in model organisms as summarized by Gamble and Zarkower (2012). Only selected key sex-specific regulators are shown. Dashed black lines indicate temporal relationships, and dashed red lines indicate hypothetical relationships based on expression data only. [Based on Zhang et al. (2014)]. FF genotype permits sex change (Guo et al. 1998).

\section{An unconventional sex determining mechanism in bivalves?}

As mentioned above, many bivalves including members of the orders Mytiloida, Unionoida, Veneroida (see reviews in Breton et al. 2007; Passamonti et al. 2009; Zouros 2013) and Nuculanoida (Boyle and Etter 2013) exhibit an unusual system of mitochondrial DNA transmission known as doubly uniparental inheritance (DUI). Under this system, two highly divergent sex-linked mitochondrial DNAs exist, transmitted respectively only through eggs and sperm. Females are normally homoplasmic for the female-transmitted mitochondrial genome (F-type) whereas males are heteroplasmic for the $\mathrm{F}$ and the male-transmitted (M-type) mitochondrial genomes (see Figure 3). Indeed, this unusual association between a male-transmitted genome and maleness is what prompted interest in the possible relationship between mitochondrial genomes and sex determination mechanisms in bivalves. One of the leading hypotheses to explain the origin and maintenance of DUI is that a male-transmitted genome might have evolved because it plays a role in sex determination (Breton et al. 2011; Zouros 2013) and this could benefit a "selfish" paternally transmitted cytoplasmic genome (Burt and Trivers 2006).

Much of the best experimental work on sex ratio biases and theoretical modelling of sex determination mechanisms in bivalves has been done on the genus Mytilus, which was the first organism shown to exhibit DUI (reviewed in Breton et al. 2007; Passamonti et al. 2009; Zouros 2013). For example, Saavedra et al. (1997) and Kenchington et al. (2002) used controlled crosses to show that offspring sex ratio is a characteristic dictated by the female parent, with individual females producing (a) all female progeny, (b) a roughly 50:50 sex ratio, or (c) 
a heavily male-biased sex ratio, regardless of the male to which they are mated. Fertilization experiments performed using mussel sperm stained with a mitochondrial dye (i.e., MitoTracker) from these same controlled crosses demonstrated that the sperm-transmitted mitochondria cluster together for the first several cell division cycles following fertilization of eggs from mothers that produce heavily male-biased crosses, whereas the paternally derived mitochondria disperse and rapidly disappear in crosses involving mothers characterized by female-biased progeny (Cao et al. 2004a; see Figure 3). Kenchington et al. (2009) suggested that the data from these controlled crosses demonstrate that paternal mtDNA and maleness are co-inherited but they argued that maleness is not caused by the male mtDNA genome directly. Zouros (2000) originally proposed a three-factor (i.e., $\mathrm{W}, \mathrm{X}$, and $\mathrm{Y}$ ) genetic model for how the mother's nuclear genotype controls the sex of the offspring. According to the model, the $\mathrm{W}$ factor is expressed on the surface of spermatozoa and it interacts with a complementary $\mathrm{X}$ factor expressed in the cytoplasm of the egg, which is coded for by the female parent. These two factors are the default system that potentially lead to the elimination of the sperm mitochondria and ensure uniparental transmission of the mother's mtDNA. However, whether this occurs is affected by a third factor, $Z$, which has two alleles; an active $\mathrm{Z}$ form that suppresses the $\mathrm{X}$ factor and facilitates paternal transmission of the M-type mtDNA, or an inactive $\mathrm{z}$ form, which does not interfere with expression of the $\mathrm{X}$ factor, enabling destruction of the paternal mitochondria (Zouros 2000). A refined version of an oligogenic sex-determination model that incorporates an additional factor, S, is presented in Zouros (2013).

\section{The doubly uniparental inheritance of mitochondria}

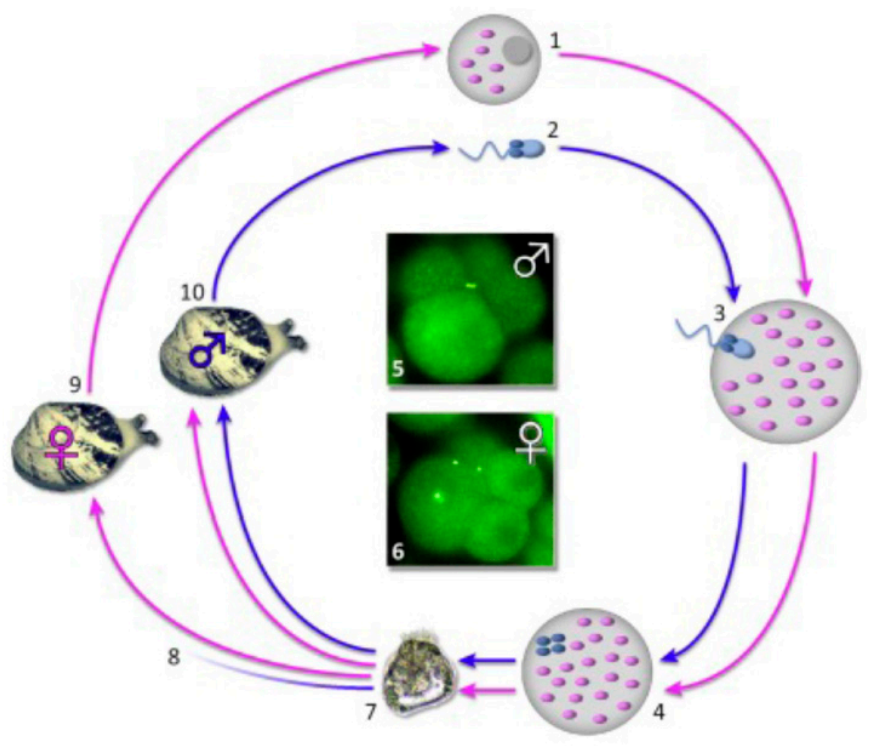

Figure 3. Scheme of mitochondrial transmission in species with doubly uniparental inheritance (DUI) of mitochondria. Pink ovals, egg mitochondria containing F mtDNA; blue ovals, sperm mitochondria carrying $\mathrm{M}$ mtDNA; pink arrows, transmission route of $\mathrm{F}$ mtDNA; blue arrows, transmission route of M mtDNA. Bright green spots in panels 5 and 6 are sperm mitochondria stained with MitoTracker ${ }^{\circledR}$ Green FM staining. The F mtDNA follows a normal transmission pattern, while the $\mathrm{M}$ follows exclusively a father-to-son one: (1) eggs are homoplasmic for $\mathrm{F}$ mitochondria, (2) sperm is homoplasmic for $\mathrm{M}$ mitochondria, (3) the spermatozoon carries $\mathrm{M}$ into the egg, (4) zygotes are heteroplasmic, (5) sperm mitochondria are aggregated in males, (6) sperm mitochondria are dispersed in females, (7) embryos continue development, (8) M is often lost in adult females, (9) adult females transmit only F with eggs, (10) adult males transmit only M with spermatozoa. [Based on Breton et al. (2014)].

Female-dependent sex-ratio biases have also been demonstrated in other DUI species (e.g., the venerid clam Ruditapes philippinarum [Ghiselli et al. 2012] and the freshwater mussel Unio delphinus [Machordom et al. 2015]), suggesting that sex-ratio bias may be a general characteristic of taxa exhibiting this unusual system of mtDNA 
inheritance. Ghiselli et al. (2011) summarized the sex-specific segregation of the $\mathrm{M}$ and F genomes in DUI species in terms of a "three-checkpoint" process. The segregation of the M type mitochondria in fertilized eggs and early stage male embryos (e.g., Cao et al. 2004a; Ghiselli et al. 2011) is Checkpoint \#1, and the destruction/dilution of the M type in early stage female embryos (Sutherland et al. 1998; Cao et al. 2004a; Guerra et al. 2016) is Checkpoint \#2. The sequestration of the $\mathrm{M}$ type in primordial germ cells in developing male gonads, and of the $\mathrm{F}$ type in the female developmental pathway, is characterized as Checkpoint \#3 (Ghiselli et al. 2011).

Some progress has been made with respect to identifying the molecular basis of these critical checkpoints for the fate of the M genome during sexual maturation. Kyriakou et al. (2015) used an electrophoretic mobility shift assay (EMSA) to demonstrate that a small DNA segment of the variable domain 1 (VD1) of the control region of a male-transmitted mitochondrial genome in Mytilus galloprovincialis forms a complex with a protein expressed in male gonad, and, more specifically, that this interaction is strongest for perinuclear mitochondria. Kyriakou et al. (2015) refer to this 23bp fragment as a sperm transmission element (STE) and suggest that the resulting protein-mitochondrial DNA complexes allow these male-derived organelles to resist degradation during spermatogenesis, thereby ensuring the paternal transmission of these genomes.

The hypothesis of a critical role for mitochondrial STEs based in the control region of male-transmitted mitochondrial genomes of Mytilus mussels come from several studies demonstrating recombination of $\mathrm{M}$ and $\mathrm{F}$ genomes in members of that genus (reviewed in Stewart et al. 2009). Various species of Mytilus mussels exhibit two distinct categories of male-transmitted genomes: one that tends to be highly divergent from the $\mathrm{F}$ type (e.g., $15-20 \%$ sequence divergence for protein coding genes), and one that tends to be quite similar (e.g., $<2-3 \%$ sequence divergence; Hoeh et al. 1996). The divergent M type is referred to as a "standard male" or SM type, whereas the other M type is referred to as a "recently masculinized" or RM type genome (Stewart et al. 2009). Sequencing studies have affirmed that Mytilus RM types are recombinant genomes (e.g., Cao et al. 2004b; Burzynski et al. 2006). These RM types are composed of an F genome protein coding, ribosomal and transfer RNA genes and, significantly, the control region from an SM type genome. The presence of the sperm transmission element elucidated by Kyriakou et al. (2015) from an SM genome control region appears to be a critical factor effecting the subsequent sequestration of the sperm-derived mitochondria in the germ cells. Recent comparative work on Mytilus sp. and the closely related horse mussel, Modiolus modiolus (Mytilidae) by Robicheau (2016) suggests that additional conserved sequence motifs in the mitochondrial control region could also function as molecular signals for the cellular mechanisms that govern paternal transmission.

One question that remains to be elucidated is whether this unusual system of DUI had its origin as a cytoplasmic sex determination system that benefitted a selfish genetic element (Breton et al. 2007; Passamonti and Ghiselli 2009; Zouros 2013). Milani et al. $(2013,2014)$ recently conducted extensive in silico analyses of molecular signatures and motifs of novel bivalve ORFan genes in the venerid $R$. philippinarum and suggested that the causative agent that lead to the creation of the DUI system may have been a selfish viral element. Although the mitochondrial genomes of some DUI taxa may no longer determine gender directly (e.g., Mytilus), it is possible that an ancestral cytoplasmic sex determination system was subsequently usurped by a nuclearencoded system. Such an evolutionary arms race between the nuclear and cytoplasmic genomes would be in keeping with the demonstration by Bachtrog et al. (2014) that sex determination systems are extremely plastic evolutionarily and subject to a variety of selective pressures. Given that sex determining mechanisms are diverse and can evolve rapidly even among closely related species (see Bachtrog et al. 2014 for a review), it would not be unreasonable to hypothesize that a selfish mitochondrial DNA element could have evolved the ability to affect a species' sex determination pathway, only to have the nuclear genome evolve a restorer locus that wrested sex determination back from the influence of a selfish mitochondrial element. For example, mitochondriallyencoded elements that distort sex ratios are well known in plants with cytoplasmic male sterility (CMS) (Chase 2007). Specifically, CMS typically involves mitochondrial genes causing sterile or inviable pollen, a situation that has been repeatedly followed by the evolution of nuclear restorer genes (Burt and Trivers 2006; Chase 2007).

In bivalves, evidence for a more direct and on-going role for mitochondrial genomes in sex determination pathways comes from recent studies of freshwater mussels of the order Unionoida, which also exhibit M- and Ftransmitted mitochondrial DNA lineages (e.g., Breton et al. 2009, 2011; Doucet-Beaupré et al. 2010). Whereas the $\mathrm{M}$ and $\mathrm{F}$ genomes in the marine mussel family Mytilidae and the marine mussel family Veneridae appear to 
experience occasional recombination between the two gender-associated mtDNA genomes leading to the creation of a new male-transmitted genome (reviewed in Stewart et al. 2009), the M and F genomes in the family Unionidae have been distinct from one another for more that 200 million years and may exhibit as much as $\sim 50 \%$ amino acid sequence divergence (Doucet-Beaupré et al. 2010). Analysis of complete $M$ and $F$ mitochondrial genomes from several dioecious (gonochoric) species of Unionoid taxa (Doucet-Beaupré et al. 2010; Breton et al. 2011) has demonstrated the presence of two unique putative ORFan genes in these genomes, one in the $F$ genome and one in the $\mathrm{M}$ genome. The $\mathrm{M}$ and F-orf genes share no obvious sequence homology to one another or to any other genes on GenBank (Breton et al. 2011). A further fascinating observation is what happens to these genes in closely related hermaphroditic species of unionoid mussels. Breton et al. (2011) showed that hermaphrodites (a) retain a genome that is derived from the F genome of their dioecious ancestor, (b) evolve a divergent "H-orf" gene derived from the F-orf gene, and (c) lose the M genome altogether. Immunohistochemical probing for the F-ORF protein has also shown that it is localized to areas outside of the mitochondrion, specifically in the nuclear membrane and nucleoplasm (Breton et al. 2011). The presence of the distinctive "ORFan" genes with no homology to known genes of the oxidative phosphorylation pathway suggests a novel role for the proteins they encode, broadening the functional repertoire of mitochondrial genomes (Breton et al. 2014). The rapid evolutionary divergence of the H-orfs (which are independently derived in several hermaphroditic species of freshwater mussels), suggests a considerable change in function of these genes associated with the reproductive switch from dioecy to hermaphroditism, and consequently, an implication of a role in sex determination or sexual development (Breton et al. 2011, 2014).

\section{Conclusion and perspectives}

The sexual strategies and sex determining mechanisms in bivalves are remarkably diverse. Mixed sex determination systems, involving both genetic and epigenetic factors have been described in many species. Bivalve species richness and diversity of sexual systems offer an excellent opportunity for addressing questions about the underlying mechanisms of sex determination. Future sex determination research in bivalves also promises to yield useful tools for selective breeding programs of economically important species. Recently developed 'omic' technologies are now capable of identifying many of the key molecular components involved in sex determination in bivalves and other animals, i.e., they enable the examination of how the expression of these key molecular components affects the physiology of the developing embryo, how this process can be affected by environmental factors, and how it can be reprogrammed in hermaphroditic species. Such approaches and studies will allow us to test hypotheses relating to the underlying factors shaping the evolution of sex determining systems.

\section{References}

1. Allen SK Jr, Hidu H, Stanley JG. 1986. Abnormal gametogenesis and sex ratio in triploid soft-shell clams (Mya arenaria). Biol. Bull. 170: 198-210.

2. Amemiya I. 1935. Effect of gill excision upon the sexual differentiation of the oyster (Ostrea gigas). Rept. fop. Ass. Adv. Sd. 10: 1025.

3. Ahmed M. 1973. Cytogenetics of oysters. Cytologia 38: 337-346.

4. Avise JC. 2011. Hermaphroditism: A Primer on the Biology, Ecology, and Evolution of Dual Sexuality. Columbia University Press.

5. Bachtrog D, Mank JE, Peichel CL, Kirkpatrick M, Otto S, Ashman T-L, Hahn M, Kitano J, Mayrose I, Ming R, Perrin N, Ross L, Valenzuela N, Vamosi JC, The Tree of Sex Consortium. 2014. Sex Determination: Why So Many Ways of Doing It? PLoS Biol. 12: e1001899.

6. Bahr LM, Hillman RE.1967. Effects of repeated shell damage on gametogenesis in the American oyster, Crassostrea virginica (Gmelin). Proc. Natl. Shellfish Assoc. 57: 59-62.

7. Bello G, Paparella P, Corriero A, Santamaria N. 2013. Protandric hermaphroditism in the bivalve Arca noae (Mollusca: Arcidae). Medit. Mar. Sci. 14: 86-91.

8. Beukeboom L, Perrin N. 2014. The evolution of sex determination. Oxford University Press. 
9. Boyle EE, Etter RJ. 2013. Heteroplasmy in a deep-sea protobranch bivalve suggests an ancient origin of doubly uniparental inheritance of mitochondria in Bivalvia. Mar. Biol. 160: 413-422.

10. Breton S, Doucet Beaupré H, Stewart DT, Hoeh WR, Blier PU. 2007. The unusual system of doubly uniparental inheritance of mtDNA: isn't one enough? Trends Genet. 23: 465-474.

11. Breton S, Beaupre HD, Stewart DT, Piontkivska H, Karmakar M, Bogan AE, Blier PU, Hoeh WR. 2009. Comparative mitochondrial genomics of freshwater mussels (Bivalvia: Unionoida) with doubly uniparental inheritance of mtDNA: gender-specific open reading frames and putative origins of replication. Genetics 183: 1575-1589.

12. Breton S, Stewart DT, Shepardson S, Trdan RJ, Bogan AE, Chapman EG, Ruminas AJ, Piontkivska H, Hoeh WR. 2011. Novel protein genes in animal mtDNA: a new sex determination system in freshwater mussels (Bivalvia: Unionoida)? Mol. Biol. Evol. 28: 1645-1659.

13. Breton S, Milani L, Ghiselli F, Guerra D, Stewart DT, Passamonti M. 2014. A resourceful genome: updating the functional repertoire and evolutionary role of animal mitochondrial DNAs. Trends Genet. 30: 555-564.

14. Burnell GM. 1995. Age-related protandry in the scallop Chlamys varia (L.) on the west coast of Ireland. ICES Mar. Sci. Symp. 199: 26-30.

15. Burt A, Trivers R. 2006. Genes in conflict: the biology of selfish genetic elements. Cambridge: Harvard Univ Press.

16. Burzynski A, Zbawicka M, Skibinski DOF, Wenne R. 2006. Doubly uniparental inheritance is associated with high polymorphism for rearranged and recombinant control region haplotypes in Baltic Mytilus trossulus. Genetics 174: 1081-1094.

17. Campos A, Tedesco S, Vasconcelos V, Cristobal S. 2012. Proteomic research in bivalves: Towards the identification of molecular markers of aquatic pollution. J. Proteomics 75: 4346-4359.

18. Cao L, Kenchington E, Zouros E. 2004a. Differential segregation patterns of sperm mitochondria in embryos of the blue mussel (Mytilus edulis). Genetics 166: 883-894.

19. Cao L, Kenchington EL, Zouros E, Rodakis GC. 2004b. Evidence that the large noncoding sequence is the main control region of maternally and paternally transmitted mitochondrial genomes of the marine mussel (Mytilus spp.). Genetics 167: 835-850.

20. Charnov EL, Maynard Smith J, Bull JJ. 1976. Why be a hermaphrodite? Nature 263: 125-126.

21. Charnov EL. 1982. The theory of sex allocation. Princeton university press.

22. Chase CD. 2007. Cytoplasmic male sterility: A window to the world of plant mitochondrial-nuclear interactions. Trends Genet. 23:81-90.

23. Chávez-Villalba J, Hernández-Ibarra A, López-Tapia MR, Mazón-Suástegui JM. 2008. Prospective culture of the Cortez oyster Crassostrea corteziensis from northwestern Mexico: growth, gametogenic activity, and condition index. J. Shellfish Res. 27: 711-720.

24. Chávez-Villalba J, Soyez C, Huvet A, Gueguen Y, Lo C, Le Moullac G. 2011. Determination of gender in the pearl oyster Pinctada margaritifera. J. Shellfish Res. 30: 231-240.

25. Ciocan CM, Cubero-Leon E, Peck MR, Langston WJ, Pope N, Minier C, Rotchell JM. 2012. Intersex in Scrobicularia plana: Transcriptomic Analysis Reveals Novel Genes Involved in Endocrine Disruption. Environ. Sci. Technol. 46: 12936-12942.

26. Coe WR. 1936. Environment and sex in the oviparous oyster Ostrea virginica. Biol. Bull. 71: 353-359.

27. Coe WR. 1943. Sexual differentiation in molluscs. 1. Pelecypoda. Q. Rev. Biol. 18: 154-164.

28. Collin R. 2013. Phylogenetic Patterns and Phenotypic Plasticity of Molluscan Sexual Systems. Integr. Comp. Biol. 53: 723-735.

29. Cornet M, Soulard C. 1989. Number and morphology of the metaphase mitotic chromosomes in Scrobicularia Plana (Da Costa, 1778) (Mollusca, Bivalvia, Tellinacea). Caryologia 42: 11-18.

30. Cornet M, Soulard C. 1990. Chromosome number and karyotype of Donax trunculus L. (Mollusca, Bivalvia, Tellinacea). Genetica 82: 93-97.

31. Cox C, Mann R. 1992. Temporal and spatial changes in fecundity of eastern oysters, Crassostrea virginica (Gmelin, 1791) in the James River, Virginia. J. Shellfish. Res. 11: 49-57. 
32. Croll RP, Wang C. 2007. Possible roles of sex steroids in the control of reproduction in bivalve molluscs. Aquaculture 272: 76-86.

33. Davis NW, Hillman RE. 1971. Effect of artificial shell damage on sex determination in oysters. Proc. Natl. Shellfish. Assoc. 61: 2.

34. Dheilly NM, Lelong C, Huvet A, Kellner K, Dubos M-P, Riviere G, Boudry P, Favrel P. 2012. Gametogenesis in the Pacific oyster Crassostrea gigas: a microarrays-based analysis identifies sex and stage specific genes. PLoS ONE 7: e36353.

35. Downing JA, Amyot J-P, Pérusse M, Rochon Y. 1989. Visceral Sex, Hermaphroditism, and Protandry in a Population of the Freshwater Bivalve Elliptio complanata. J. N. Am. Benthol. Soc. 8: 92-99.

36. Doucet-Beaupré H, Breton S, Chapman EG, Blier PU, Bogan AE, Stewart DT, Hoeh WR. 2010. Mitochondrial phylogenomics of the Bivalvia (Mollusca): searching for the origin and mitogenomic correlates of doubly uniparental inheritance of mtDNA. BMC Evol. Biol. 10.

37. Egami N. 1953. Studies on sexuality in the Japanese oyster, Ostrea gigas. VII. Effects of gill removal on growth and sexuality. Annotat. Zool. Jap. 26: 145-150.

38. Evans JP, Sherman CDH. 2013. Sexual Selection and the Evolution of Egg-Sperm Interactions in Broadcast-Spawning Invertebrates. Biol. Bull. 224: 166-183.

39. Fabioux C, Pouvreau S, Le Roux F, Huvet A. 2004. The oyster vasa-like gene: a specific marker of the germline in Crassostrea gigas. Biochem. Biophys. Res. Commun. 315: 897-904.

40. Fabioux C, Huvet A, Le Souchu P, Le Pennec M, Pouvreau S. 2005. Temperature and photoperiod drive Crassostrea gigas reproductive internal clock. Aquaculture 250: 458-470.

41. Fabioux C, Corporeau C, Quillien V, Favrel P, Huvet A. 2009. In vivo RNA interference in oyster--vasa silencing inhibits germ cell development. FEBS J. 276: 2566-2573.

42. Gagné F, Blaise C, Pellerin J, Pelletier E, Douville M, Gauthier-Clerc S, Viglino L. 2003. Sex alteration in soft-shell clams (Mya arenaria) in an intertidal zone of the Saint Lawrence River (Quebec, Canada). Comp. Biochem. Physiol. C. 134: 189-198.

43. Galbraith HS, Vaughn CC. 2011. Effects of reservoir management on abundance, condition, parasitism and reproductive traits of downstream mussels. River Res. Applic. 27: 193-201.

44. Gamble T, Zarkower D. 2012. Sex determination. Curr. Biol. 22: R257-R262.

45. Gauthier-Clerc S, Pellerin J, Blaise C, Gagné F. 2002. Delayed gametogenesis of Mya arenaria in the Saguenay fjord (Canada): a consequence of endocrine disruptors? Comp Biochem Physiol C. 131: 457467.

46. Ghiselin MT. 1969. The evolution of hermaphroditism among animals. Quart. Rev. Biol. 44: 189-208.

47. Ghiselli F, Milani L, Passamonti M. 2011. Strict Sex-Specific mtDNA Segregation in the Germ line of the DUI Species Venerupis philippinarum (Bivalvia: Veneridae). Mol. Biol. Evol. 28: 949-961.

48. Ghiselli F, Milani L, Chang PL, Hedgecock D, Davis JP, Nuzhdin SV, Passamonti M. 2012. De novo assembly of the manila clam Ruditapes philippinarum transcriptome provides new insights into expression bias, mitochondrial doubly uniparental inheritance and sex determination. Mol. Biol. Evol. 29: 771-786.

49. Gosling EM. 2015. Marine bivalve molluscs, $2^{\text {nd }}$ edition. Wiley-Blackwell Publishing.

50. Guerra D, Ghiselli F, Milani L, Breton S, Passamonti M. 2016. Early replication dynamics of sex linked mitochondrial DNAs in the doubly uniparental inheritance species Ruditapes philippinarum (Bivalvia Veneridae). Heredity 116: 324-332.

51. Guo X, Allen SK. 1994. Sex determination and polyploid gigantism in the dwarf surfclam (Mulinia lateralis Say). Genetics 138: 1199-1206.

52. Guo X, Hedgecock D, Hershberger WK, Cooper K, Allen SK. 1998. Genetic determinants of protandric sex in the Pacific oyster, Crassostrea gigas Thunberg. Evolution 52: 394-402.

53. Haley LE. 1977. Sex determination in the American oyster. J. Hered. 68: 114-116.

54. Haley LE. 1979. Genetics of sex determination in the American oyser. Proc. Nat. Shellfish Assoc. 69: 5457.

55. Hedrick PW, Hedgecock D. 2010. Sex determination: genetic models for oysters. J. Hered. 101: 602-611. 
56. Heller J. 1993. Hermaphroditism in molluscs. Biol. J. Linn. Soc. 48: 19-42.

57. Hinzmann M, Lopes-Lima M, Teixeira A, Varandas S, Sousa R, Lopes A, Froufe E, Machado J. 2013. Reproductive cycle and strategy of Anodonta anatina (L., 1758): Notes on hermaphroditism. J. Exp. Zool. 319A: 378-390.

58. Hoeh WR, Stewart DT, Sutherland BW, Zouros E. 1996b. Multiple origins of gender-associated mitochondrial DNA lineages in bivalves (Mollusca: Bivalvia). Evolution 50: 2276-2286.

59. Jenkinson JJ. 2014. Chromosomal characteristics of North American and other naiades (Bivalvia: Unionida). Malacologia 57: 377-397.

60. Jiao W, Fu X, Dou J, Li H, Su H, Mao J, Yu Q, Zhang L, Hu X, Huang X, et al. 2014. High-resolution linkage and quantitative trait locus mapping aided by genome survey sequencing: building up an integrative genomic framework for a bivalve mollusc. DNA Res 21: 85-101.

61. Johnston MO, Das B, Hoeh WR. 1998. Negative correlation between male allocation and rate of selffertilization in a hermaphroditic animal. Proc. Natl. Acad. Sci. USA 95: 617-620.

62. Kamiya T, Kai W, Tasumi S, Oka A, Matsunaga T, Mizuno N, Fujita M, Suetake H, Suzuki S, Hosoya S, et al. 2012. A trans-species missense SNP in Amhr2 is associated with sex determination in the tiger pufferfish, Takifugu rubripes (Fugu). PLOS Genet 8: e1002798.

63. Kenchington E, MacDonald B, Cao L, Tsagarakis D, Zouros E. 2002. Genetics of mother-dependent sex ratio in blue mussels (Mytilus spp.) and implications for doubly uniparental inheritance of mitochondrial DNA. Genetics 161: 1579-1588.

64. Kenchington EL, Hamilton L, Cogswell A, Zouros E. 2009. Paternal mtDNA and maleness are coinherited but not causally linked in mytilid mussels. PLoS ONE 4: e6976.

65. Kennedy VS. 1983. Sex ratios in oysters, emphasizing Crassostrea virginica from Chesapeake Bay, Maryland. Veliger 25: 329-338.

66. Kopp A. 2012. Dmrt genes in the development and evolution of sexual dimorphism. Trends Genet. 28: 175-184.

67. Korpelainen H. 1990. Sex ratios and conditions required for environmental sex determination in animals. Biol. Rev. 65: 147-184.

68. Kyriakou E, Kravariti L, Vasilopoulos T, Zouros E, Rodakis GC. 2015. A protein binding site in the M mitochondrial genome of Mytilus galloprovincialis may be responsible for its paternal transmission. Gene 562: 83-94.

69. Lango-Reynoso F. 1999. Détermination de la sexualité chez l'huître Crassostrea gigas (Thunberg, 1793). Doctoral Thesis, Université de Bretagne Occidentale, Brest, France. 176 pp.

70. Lango-Reynoso F, Chávez-Villaba J, Le Pennec M. 2006. Reproductive patterns of the Pacific oyster Crassostrea gigas in France. Invertebr. Reprod. Dev. 49: 41-50.

71. Legube G, McWeeney SK, Lercher MJ, Akhtar A. 2006. X-chromosome-wide profiling of MSL-1 distribution and dosage compensation in Drosophila. Genes Dev. 20: 871-883.

72. Leitão A, Chaves R. 2008. Banding for chromosomal identification in bivalves: a 20- year history. Dyn. Biochem. Process Biotechnol. Mol. Biol. 2: 44-49.

73. Llera-Herrera R, García-Gasca A, Abreu-Goodger C, Huvet A, Ibarra AM. 2013. Identification of male gametogenesis expressed genes from the scallop Nodipecten subnodosus by suppressive subtraction hybridization and pyrosequencing. PLoS ONE 8: e73176.

74. Lubet P. 1959. Recherches sur le cycle sexuel et l'émission des gametes chez les mytilides et les pectinides (Mollusques bivalves). Rev. Trav. Inst. Pêches Marit. 23: 387-548.

75. Lucas A. 1965. Recherche sur la sexualité des mollusques bivalves. Bull. Biol. Fr. Berg. 99: 115-247.

76. Machordom A, Araujo R, Toledo C, Zouros E, Ladoukakis ED. 2015. Female-dependant transmission of paternal mtDNA is a shared feature of bivalve species with doubly uniparental inheritance (DUI) of mitochondrial DNA. J. Zoolog. Syst. Evol. Res. 53: 200-204.

77. Mackie GL. 1984. Bivalves. In Tompa A, Verdonk NH, Biggelaar JA, eds. The Mollusca, Vol. 7. Reproduction New York: Academic Press, 351-418.

78. Manolakou P, Lavranos G, Angelopoulou R. 2006. Molecular patterns of sex determination in the animal 
kingdom: a comparative study of the biology of reproduction. Reprod. Biol. Endocrinol. 4: 59.

79. Matsumoto T, Masaoka T, Fujiwara A, Nakamura Y, Satoh N, Awaji M. 2013. Reproduction-related genes in the pearl oyster genome. Zool. Sci. 30: 826-850.

80. McMahon RF. 1999. Invasive characteristics of the freshwater bivalve Corbicula fluminea.

81. In: Claudi R, Leach JH (eds). Nonindigenous Freshwater Organisms: Vectors, Biology and

82. Impact. Lewis Press, Washington, DC, pp 315-343.

83. McKoy JL. 1980. Biology, exploitation and management of giant clams (Tridacnidae) in the Kingdom of Tonga. Fish. Bull. Tongu 1: 1-6.

84. Menzel RW. 1968. Chromosome number in nine families of marine pelecypod mollusks. Nautilus 82: 4950.

85. Merrill AS, Burch JB. 1960. Hermaphroditism in the sea scallop Placopecten magellanicus. Biol. Bull. 119: 197-201.

86. Milani L, Ghiselli F, Guerra D, Breton S, Passamonti M. 2013. A comparative analysis of mitochondrial ORFans: new clues on their origin and role in species with doubly uniparental inheritance of mitochondria. Genome Biol. Evol. 5: 1408-1434.

87. Milani L, Ghiselli F, Maurizii MG, Nuzhdin S V., Passamonti M. 2014. Paternally transmitted mitochondria express a new gene of potential viral origin. Genome Biol. Evol. 6: 391-405.

88. Mori K, Muramatsu T, Nakamura Y. 1969. Effect of steroid on oyster III: sex reversal from male to female in Crassostrea gigas by estradiol-17ß. Bull. Jap. Soc. Sci. Fish. 35: 1072-1076.

89. Morton B. 1981. The Anomalodesmata. Malacologia 21: 35-60.

90. Morton B. 1991. Do the Bivalvia demonstrate environment-specific sexual strategies? A Hong Kong model. J. Zool. Lond. 223: 131-142.

91. Moss SM. 1989. Effects of exogenous androgens on growth, biochemical composition, and reproduction of the coot clam, Mulinia lateralis. Pac. Sci. 43: 200.

92. Naimi A, Martinez A-S, Specq M-L, Mrac A, Diss B, Mathieu M, Sourdaine P. 2009a. Identification and expression of a factor of the DM family in the oyster Crassostrea gigas. Comp. Biochem. Physiol. A Mol. Integr. Physiol. 152: 189-196.

93. Naimi A, Martinez A-S, Specq M-L, Diss B, Mathieu M, Sourdaine P. 2009b. Molecular cloning and gene expression of Cg-Foxl2 during the development and the adult gametogenetic cycle in the oyster Crassostrea gigas. Comp. Biochem. Physiol. B Biochem. Mol. Biol. 154: 134-142.

94. Naylor, RL, Goldburg RJ, Primavera JH, Kautsky N, Beveridge, MC, Clay J, Folke C, Lubchenco J, Mooney H, Troell M. 2000. Nature 405: 1017-1024.

95. Oldfield E. 1961. The functional morphology of Kellia suborbicularis (Montagu), Montacuta ferruginosa (Montagu) and M. substriata (Montagu), (Mollusca, Lamellibranchiata). J. Mollus. Stud. 34: 255-295.

96. Park JJ, Shin YK, Hung SSO, Romano N, Cheon Y-P, Kim JW. 2015 Reproductive impairment and intersexuality in Gomphina veneriformis (Bivalvia: Veneridae) by the tributyltin compound. Anim. Cells Syst. 19: 61-68.

97. Passamonti M, Ghiselli F. 2009. Doubly Uniparental Inheritance: Two Mitochondrial Genomes, One Precious Model for Organelle DNA Inheritance and Evolution. DNA and Cell Biol. 28: 79-89.

98. Pigneur L-M, Marescaux J, Roland K, Etoundi E, Descy J-P, Van Doninck K. 2011. Phylogeny and androgenesis in the invasive Corbicula clams (Bivalvia, Corbiculidae) in Western Europe. BMC Evol. Biol. 11: 147.

99. Pigneur L-M, Hedtke SM, Etoundi E, Van Doninck K. 2012. Androgenesis: a review through the study of selfish shellfish Corbicula spp. Heredity 108: 581-591.

100.Policansky D. 1982. Sex change in plants and animals. Ann. Rev. Ecol. Syst. 13: 471-495.

101.Purchon RD. 1968. The biology of the Mollusca. Oxford Pergamon Press. 560 pp.

102.Rhen T, Metzger K, Schroeder A, Woodward R. 2007. Expression of putative sex determining genes during the thermosensitive period of gonad development in the snapping turtle, Chelydra serpentina. Sex. Dev. 1: 255-270.

103.Robicheau BM. 2016. Doubly uniparental inheritance of mitochondrial DNA in the marine horse mussel 
(Modiolus modiolus): a comparison of female- and male-associated mitochondrial genomes. Msc. Thesis, Acadia University, Wolfville, N.S. 170 pp.

104. Rodríguez-Jaramillo C, Hurtado MA, Romero-Vivas E, Ramírez JL, Manzano M, Palacios E. 2008. Gonadal development and histochemistry of the tropical oyster, Crassostrea corteziensis (Hertlein, 1951) during an annual reproductive cycle. J. Shellfish Res. 27: 1129-1141.

105. Romo Piñera Ak, Ceballos-Vázquez BP, García-Domínguez F, Arellano-Martínez M. 2009. Unusual high frequency of hermaphroditism in the gonochoric bivalve Megapitaria Squalida (Sowerby, 1835) (Veneridae). J. Shellfish Res. 28: 785-789.

106. Russell-Hunter WD. 1979. The evolution of filter-feeding bivalves. In: A life of invertebrates. New York: MacMillan Publishing.

107.Saavedra C, Reyero MI, Zouros E. 1997. Male-dependent doubly uniparental inheritance of mitochondrial DNA and female-dependent sex ratio in the mussel Mytilus galloprovincialis. Genetics 145: 1073-1082.

108.Santerre C, Sourdaine P, Martinez A-S. 2012. Expression of a natural antisense transcript of Cg-Foxl2 during the gonadic differentiation of the oyster Crassostrea gigas: first demonstration in the gonads of a lophotrochozoa species. Sex. Dev. 6: 210-221.

109.Santerre C, Sourdaine P, Adeline B, Martinez A-S. 2014. Cg-SoxE and Cg- $\beta$-catenin, two new potential actors of the sex-determining pathway in a hermaphrodite lophotrochozoan, the Pacific oyster Crassostrea gigas. Comp. Biochem. Physiol. Part A Mol. Integr. Physiol. 167: 68-76.

110.Sastry AN. 1968. Relationship among food, temperature and gonad development of the bay scallop Argopecten irradians Lamarck. Physiol. Zool. 6: 374-375.

111.Sastry AN. 1979. Pelecypoda (excluding ostreidae). In: AC Giese and JC Pearse, editors. Reproduction of Marine Invertebrates. New York: Academic Press. pp 113-192.

112.Shi J, Hong Y, Sheng J, Peng K, Wang J. 2015. De novo transcriptome sequencing to identify the sexdetermination genes in Hyriopsis schlegelii. Biosc. Biotechnol. Biochem. 79: 1257-1265.

113.Shoemaker-Daly CM, Jackson K, Yatsu R, Matsumoto Y, Crews D. 2010. Genetic network underlying temperature-dependent sex determination is endogenously regulated by temperature in isolated cultured Trachemys scripta gonads. Dev. Dyn. 239: 1061-1075.

114.Shumway SE (Ed.). 2011. Shellfish aquaculture and the environment. Wiley-Blackwell.

115.Shumway SE, Parsons GJ (Eds.). 2011. Scallops: biology, ecology and aquaculture (Vol. 40). Elsevier.

116.Soria RG, Pascual MS, Cartes VHF. 2002. Reproductive cycle of the cholga paleta Atrina seminuda Lamarck 1819 (Bivalvia Pinnidae) from northern Patagonia, Argentina. J. Shellfish Res. 21: 479-488.

117.Stenyakina A, Walters LJ, Hoffman EA, Calestani C. 2010. Food availability and sex reversal in Mytella charruana, an introduced bivalve in the southeastern United States. Mol. Reprod. Dev. 77: 222-230.

118.Stewart DT, Breton S, Blier PU, Hoeh WR. 2009. Masculinization events and doubly uniparental inheritance of mtDNA: A model for understanding the evolutionary dynamics of gender-asssociated mtDNA in mussels. In Pontarotti P, editor. Evolutionary Biology from Concept to Application II. Berlin: Springer-Verlag. pp. 163-173.

119.Sutherland B, Stewart D, Kenchington ER, Zouros E. 1998. The fate of paternal mitochondrial DNA in developing female mussels, Mytilus edulis: implications for the mechanism of doubly uniparental inheritance of mitochondrial DNA. Genetics 148: 341-347.

120.Teaniniuraitemoana V, Huvet A, Levy P, Klopp C, Lhuillier E, Gaertner-Mazouni N, Gueguen Y, Le Moullac G. 2014. Gonad transcriptome analysis of pearl oyster Pinctada margaritifera: identification of potential sex differentiation and sex determining genes. BMC Genomics 15: 491.

121. Teaniniuraitemoana V, Huvet A, Levy P, Gaertner-Mazouni N, Gueguen Y, Le Moullac, G. 2015. Molecular signatures discriminating the male and the female sexual pathways in the pearl oyster Pinctada margaritifera. PLoS ONE 10: e0122819.

122. Teaniniuraitemoana V, Leprêtre M, Levy P, Vanaa V, Parrad S, Gaertner-Mazouni N, Gueguen Y, Huvet A, Le Moullac G. 2016. Effect of temperature, food availability, and estradiol injection on gametogenesis and gender in the pearl oyster Pinctada margaritifera. J. Exp. Zool. 325A: 13-24. 
123. Thiriot-Quiévreux C. 2002. Review of the literature on bivalve cytogenetics in the last ten years. Cah. Biol. Mar. 43: 17-26.

124. Thiriot-Quiévreux C, Insua A. 1992. Nucleolar organiser region variation in the chromosomes of three oyster species. J. Exp. Mar. Biol. Ecol. 157: 33-40.

125. Tong Y, Zhang Y, Huang J, Xiao S, Zhang Y, Li J, Chen J, Yu Z. 2015. Transcriptomics analysis of Crassostrea hongkongensis for the discovery of reproduction-related genes. PLoS ONE 10: e0134280.

126. Tsuda M, Sasaoka Y, Kiso M, Abe K, Haraguchi S, Kobayashi S, Saga Y. 2003. Conserved role of nanos proteins in germ cell development. Science 301: 1239-1241.

127. Van Doninck K, Schön I, De Bruyn L, Martens K. 2002. A general purpose genotype in an

128. ancient asexual. Oecologia 132: 205-212.

129. Vaught KC. 1989. A classification of the living Mollusca. Melbourne, Florida: American Malacologists Inc.

130. Veitia RA. 2010. FOXL2 vs. SOX9: A lifelong “battle of the sexes”. Bioessays 32: 375-380.

131. Wada K. 1978. Chromosome karyotypes of three bivalves: the oysters, Isognomon alatus and Pinctada imbricata, and the bay scallop, Argopecten irradians. Biol. Bull. 155: 235-245.

132. Wallis MC, Waters PD, Graves JA. 2008. Sex determination in mammals - before and after the evolution of SRY. Cell. Mol. Life Sci. 65: 3182.

133.Wang C, Croll RP. 2004. Effects of sex steroids on gonadal development and gender determination in the sea scallop, Placopecten magellanicus. Aquaculture 238: 483-498.

134. Yamaguchi T, Yamaguchi S, Hirai T, Kitano T. 2007. Follicle-stimulating hormone signaling and Foxl2 are involved in transcriptional regulation of aromatase gene during gonadal sex differentiation in Japanese flounder, Paralichthys olivaceus. Biochem. Biophys. Res. Commun. 359: 935-940.

135. Yanovych LM, Pampura MM, Vasilieva LA, Mezhherin SV. 2010. Mass hermaphroditism of Unionidae (Mollusca, Bivalvia, Unionidae) in the Central Polissya region. Rep. Nat. Acad. Sci. Ukraine 6: 158-167.

136. Yu FF, Wang MF, Zhou L, Gui JF, Yu XY. 2011. Molecular cloning and expression characterization of Dmrt2 in Akoya Pearl oysters, Pinctada Martensii. J. Shellfish Res. 30: 247-254.

137.Zhang N, Xu F, Guo X. 2014. Genomic analysis of the Pacific oyster (Crassostrea gigas) reveals possible conservation of vertebrate sex determination in a mollusc. G3 (Bethesda) 4: 2207-2217.

138.Zouros E. 2000. The exceptional mitochondrial DNA system of the mussel family Mytilidae. Genes Genet. Syst. 75: 313-318.

139.Zouros E. 2013. Biparental inheritance through uniparental transmission: the doubly uniparental inheritance (DUI) of mitochondrial DNA. Evol. Biol. 40: 1-31. 